\title{
Efficient Callus Initiation and Plantlet Regeneration of Citrus japonica Margarita
}

\author{
Mohammed Raqibul Hasan ${ }^{1}$, Anup Gupta ${ }^{1}$, Md. Nazmul Hasan ${ }^{1}$, Shahariar \\ Mohammed Fahim ${ }^{2}$, Hanif Mohammad Rejwan ${ }^{1}$, Md. Abdullah Shamim², Md. \\ Abu Talha Siddique ${ }^{2}$, Shamsul H. Prodhan ${ }^{1}$ \\ ${ }^{I}$ Department of Genetic Engineering \& Biotechnology, School of Life Sciences, Shahjalal University of Science \\ \& Technology, Sylhet-3114, Bangladesh. \\ ${ }^{2}$ Pharmacy Discipline, Khulna University, Khulna-9208, Bangladesh.
}

\begin{abstract}
In vitro approaches has become necessary for overcoming the hurdles of cultivation of Citrus, a commercially important fruit. The present study deals with establishment of protocol for micro propagation of Citrus Japonica Margarita through callus induction and regeneration. Mature seeds of this variety of citrus are used as explant. The Explants were cultured on Murashige and Skoog medium (MS) containing $30 \mathrm{~g} / \mathrm{L}$ sucrose and $7 \mathrm{~g} / \mathrm{L}$ agar supplemented with different concentrations and combinations of different phyto-hormones; 6benzylaminopurine (BA), naphthalene acetic acid (NAA), 2,4-dichloro phenoxy acetic acid $(2,4 \mathrm{D})$. The maximum callus induction (88\%) was observed from the mature seeds of Citrus japonica observed on MS medium supplemented with 2,4 D $16 \mu \mathrm{M}$. Maximum shoot regeneration response (70\%) was observed on MS medium supplemented with $B A 13.0 \mu M$. Maximum root regeneration response (80\%) was observed on $M S$ medium supplemented with IBA $10 \mu \mathrm{M}$ and when it is supplemented with NAA $5 \mu \mathrm{M}$ it is $70 \%$. The regenerated plantlets were successfully acclimatized in pots containing sterile soil mixture to study their response in in vivo conditions.
\end{abstract}

Keywords: Citrus japonica Margarita,In vitro, Callus induction, Shoot formation, Explant, Rooting.

\section{Introduction}

Citrus is considered as the number one fruit of the world due to its high nutritional value, great production potential and preparation of large number of fruit products from them. Citrus species are cultivated in most tropical and subtropical regions of the world. The genus citrus includes more than 162 species belonging to the Order Geraniales family Rutaceae and sub family Aurantoideae. Kumquat (Citrus japonica), Sweet orange (C. sinensis L. Osbeck), Grapefruit (C. paradisiMacf.), Pummelo (C. grandisOsbeck), Acid Lime (C. aurantifoliaChristm) and Lemon (C. limon (L) Burn F.) etc. are commercially grown in the world. Citrus fruit has been cultivated in an ever-widening area since ancient times; the best-known examples are the oranges, lemons, grapefruit, and limes. Citrus japonica Margarita, or Fortunella japonica, is a species of kumquat, also known as Nagami Kumquat have been called "the little gems of the citrus family"(Morton, J. 1987. Kumquat. p. 182-185. In: Fruits of warm climates). Kumquat (cumquat) in Cantonese Chinese, means golden (Kum) and "Quat" meaning good fortune. It is regarded as the golden orange in China. This species lives only in climates with hot summers, with temperatures ranging from 25 to $30{ }^{\circ} \mathrm{C}\left(77^{\circ}\right.$ to $\left.86{ }^{\circ} \mathrm{F}\right)$. However, it is remarkably tolerant of frost, sometimes withstanding temperatures as low as $-8^{\circ} \mathrm{C}\left(18^{\circ} \mathrm{F}\right)$.

Propagation of orange trees is deceptively difficult, because hardy edible oranges are not generally grown from seed. Cultivars that produce good quality fruit are highly susceptible to root diseases. Grafted trees also begin bearing fruit many years earlier than trees reproduced by seed. Other benefits of grafting include more accurate reproduction of good fruit traits than plants derived from seed, and the opportunity to alter tree size, productivity, and other traits through rootstock influence, while maintaining identical fruit characteristics. Almost all orange trees are propagated in two stages. First, rootstock is grown from seed. When the seedling is well-established, the leafy top is cut off, and bud wood from an existing tree is grafted onto the rootstock. It is the bud wood that determines the variety of orange that is grown. Plant tissue culture is a collection of techniques used to maintain or grow plant cells, tissues or organs under sterile conditions on a nutrient culture medium of known composition. Plant tissue culture is widely used to produce clones of a plant in a method known as micropropagation. Different techniques in plant tissue culture may offer certain advantages over traditional methods of propagation, including: The production of exact copies of plants that produce particularly good flowers, fruits, or have other desirable traits. To quickly produce mature plants. The production of multiples of plants in the absence of seeds or necessary pollinators to produce seeds. The regeneration of whole plants from plant cells that have been genetically modified. The production of plants in sterile containers that allows them to be moved with greatly reduced chances of transmitting diseases, pests, and pathogens. Citrus 
varieties are propagated by both sexual and asexual methods. An efficient tissue culture protocol is a prerequisite for the Agrobacterium-mediated transformation of any plant. Tissue culture and micropropagation protocols have been described for a number of citrus species and explants sources (Grinblat 1972., Chaturvedi and Mitra 1974., Barlass and Skene 1982., Edriss and Burger 1984., Duran -Vila et al., 1989). Plant tissue culture technology has been successfully used for the commercial production of microbe free plants (Parmessur et al., 2002; Liao et al., 2004) and to conserve the germplasm of rare and endangered plant species to conserve them from extinction (Milkulik, 1999; Chang et al., 2000; Jaime and Da Silva, 2003). This technique involves callus induction from explants, morphogenesis, shoot development and finally root development to regenerate into a complete somaclone. All these steps require different sets of hormones and growth medium for developing somaclonal variants successfully. The importance of tissue culture in citrus research was recognized long back, and amply emphasized by Bitters and Murashige (1967) and Kochba and Spiegel-Roy (1976). The far reaching significance of tissue culture in citrus breeding for improvement and augmenting production was discussed by Kochba and Spiegel-Roy (1977) and various other aspects of citrus tissue culture by Button and Kochba, (1977) and Spiegel-Roy and Kochba (1980). Plant tissue culture techniques can be applied as a helpful tool to reduce the time for improvement of orange through somaclonal variations. Techniques like in vitro culture made it easy to improve citrus against different abiotic stresses, low yield and conserve important citrus genetypes through exploiting somaclonal variations, somatic cell hybridization (Kobayashi, et al, 1992; Deng et al. 2000), transformation of high yielding cutivers disease free plants. The Citrus japonica trees smaller growing and dwarf in nature, making it ideal for pots and has even been used in bonsai. Moreover, the tree can be hydrophytes grown in water, with the fruit often found floating on water near shore during the ripe season. So it is very much helpful to grow in a rainy area like Sylhet. The present study was done to develop an efficient callus initiation system of Citrus japonica through tissue culture which might be used in an efficient and suitable regeneration protocol of orange in future

\section{Material and Methods}

This research work was conducted at the Plant Genetic Engineering Laboratory of the Department of Genetic Engineering \& biotechnology, Shahjalal University of Science \& Technology (SUST), Sylhet 3114, Bangladesh.The detail of methods employed during this study is given below:

\section{Collection of explant}

Healthy seeds of kinnow mandarin (Citrus reticulata) were used as explant for in vitro regeneration. Fresh healthy seeds of kinnow mandarin (Citrus reticulata) plant were collected from BRAC, Gazipur, Dhaka and Citrus Research Institute, Jointapur, Sylhet.

\section{Explant sterilization}

Seeds of $C$. reticulata were washed by using detergents for 2 minutes. Then explants were immersed for 15 minutes with 2 or 3 drops of Tween-20. In order to remove all traces of detergents and Tween-20 from the surface, explants were washed by sterile-distilled water for 3-4 times.

\section{Media for callus induction}

For callus induction popular callus inducing hormone 2,4-D, BA and different combination 2,4-D + BA + NAA was used. Seeds cultured on MS (Murashige and Skoog 1962) basal medium supplemented with hormonal concentration of 2,4-D varying in from $4.0 \mu \mathrm{M}$ to $18.0 \mu \mathrm{M}$. BA with concentrations varying in from $5.0 \mu \mathrm{M}$ to $11.0 \mu \mathrm{M}$ and combination of 2,4-D + BA + NAA were prepared separately in conical flasks then $0.7 \%$ agar was added and melted by boiling at $110^{\circ} \mathrm{C}$ for $2-3$ minute. After melting the agar, the media was autoclaved at $121^{\circ} \mathrm{C}$ and 15 psi for 15 minute. Than media was allowed to cool down and coagulate in the Laminar Air Flow Cabinet. Visual observation was taken every 7 days and effect of different treatment was quantified on the basis of percentage of callus induction.

\section{Shoot formation media}

Shoot generation was carried out from calli. A healthy portion of the callus was taken and cut into pieces and these pieces were placed on shoot initiation medium. Full strength MS medium supplemented with BA varying from $6.0 \mu \mathrm{M}$ to $18.0 \mu \mathrm{M}$ alone and combination with other hormones BA + KIN (9.0+10.0) $\mu \mathrm{M}$, $\mathrm{BA}+\mathrm{KIN}(13.0+14.0) \mu \mathrm{M}, \mathrm{Ba}+\mathrm{KIN}(18+19) \mu \mathrm{M}, \mathrm{BA}+\mathrm{KIN}+\mathrm{NAA}(5+2+2.5) \mu \mathrm{M}, \mathrm{BA}+\mathrm{KIN}+\mathrm{NAA}$ $(7+5+5.5) \mu \mathrm{M}$ and $\mathrm{BA}+\mathrm{KIN}+\mathrm{NAA}(9+7.5+7) \mu \mathrm{M}$ were used for shoot induction. Visual observation was taken every seven days and effect of different treatment was quantified on the basis of percentage of calli showing response for shoot regeneration. 


\section{Rooting of In vitro grown Micro shoot culture}

The In vitro grown Micro shoot were inoculated into the full strength MS media supplemented with different concentration of Auxin IBA, NAA alone and in combination were used for root induction. IBA (5.5, $7.0,10.0,12.0,14.0,15.0) \mu \mathrm{M}, \mathrm{NAA}(5.0,7.5) \mu \mathrm{M}$ and a combination of IBA + NAA $(5.0+3.0,5.0+4.5) \mu \mathrm{M}$. Statistical analysis

All the data were recorded at regular interval for analysis and reckoned under statistical basis. Arithmetic mean (A.M.) and standard deviation (S.D.) were evaluated by analyzing data with Microsoft excel 2007. Standard error (S.E.) was calculated by dividing standard deviation by square root of the total 20 replications for a single variety in each hormonal concentration. In case of our experiment error related to contamination was calculated properly and expected values were taken from the calculation.

\section{Callus induction from mature seeds of orange}

\section{Results}

In order to establish an efficient in vitro callus induction system of orange this experiment work was conducted aseptically. And then explants were cultured on MS medium supplemented with different concentration and combination of hormones. When isolated seed embryos were introduced in the MS medium they were light green. Approximately $80 \%$ of the callus was nodular compact, while $20 \%$ was smooth and compact. The color of the callus produced was light green, whitish green, yellowish green and light brown. Differences between various treatment was observed when different concentration of 2,4 D $(4,9,13,16,18$ $\mu \mathrm{M})$, BA $(5,9,11 \mu \mathrm{M})$, combination of BA, NAA and KIN were added to MS medium for the induction and proliferation of callus (Table: 1). The best callus induction response of seed was observed on MS medium supplemented with $2,4 \mathrm{D} 16 \mu \mathrm{M}$ is $88 \%$ and on MS medium supplemented with $2,4 \mathrm{D}(5 \mu \mathrm{M})$, BA $(2 \mu \mathrm{M})$ and NAA $(3 \mu \mathrm{M})$ is $77 \%$ (Fig. 1).

Table: (1) Effects of concentrations and combinations of 2,4-D, BA, NAA, KIN, for callus induction \& growth after 8 weeks of incubation.

\begin{tabular}{|c|c|c|c|c|c|c|}
\hline Hormones & $\begin{array}{l}\text { Concentrationof } \\
\text { hormones }(\mu \mathrm{M})\end{array}$ & $\begin{array}{c}\text { Numberof } \\
\text { explantinoculated }\end{array}$ & $\begin{array}{c}\text { Number } \\
\text { ofexplant } \\
\text { survived }\end{array}$ & $\begin{array}{c}\text { Percent of } \\
\text { callus } \\
\text { induction }\end{array}$ & $\begin{array}{c}\text { Color of } \\
\text { the } \\
\text { callus } \\
\end{array}$ & $\begin{array}{l}\text { Type of } \\
\text { the callus }\end{array}$ \\
\hline \multirow{5}{*}{ 2,4 - D } & 4 & 10 & 6 & 0 & Light green & $\begin{array}{l}\text { Nodular } \\
\text { compact }\end{array}$ \\
\hline & 9 & 10 & 9 & 33 & $\begin{array}{l}\text { Yellowish } \\
\text { green }\end{array}$ & $\begin{array}{l}\text { Nodular } \\
\text { compact }\end{array}$ \\
\hline & 13 & 10 & 10 & 70 & $\begin{array}{c}\text { Whitish } \\
\text { green }\end{array}$ & $\begin{array}{l}\text { Smooth } \\
\text { compact }\end{array}$ \\
\hline & 16 & 10 & 8 & 88 & $\begin{array}{c}\text { Yellowish } \\
\text { green }\end{array}$ & $\begin{array}{l}\text { Nodular } \\
\text { compact }\end{array}$ \\
\hline & 18 & 10 & 9 & 55 & $\begin{array}{l}\text { Yellowish } \\
\text { green }\end{array}$ & $\begin{array}{l}\text { Smooth } \\
\text { compact }\end{array}$ \\
\hline \multirow{3}{*}{ BA } & 5 & 10 & 8 & 25 & $\begin{array}{l}\text { Yellowish } \\
\text { green }\end{array}$ & $\begin{array}{l}\text { Nodular } \\
\text { compact }\end{array}$ \\
\hline & 9 & 10 & 9 & 33 & $\begin{array}{l}\text { Light } \\
\text { brown }\end{array}$ & $\begin{array}{l}\text { Nodular } \\
\text { compact }\end{array}$ \\
\hline & 11 & 10 & 8 & 62 & $\begin{array}{l}\text { Light } \\
\text { brown }\end{array}$ & $\begin{array}{l}\text { Nodular } \\
\text { compact }\end{array}$ \\
\hline \multirow{3}{*}{$\begin{array}{c}2,4- \\
\mathrm{D}+\mathrm{BA}+\mathrm{NAA}\end{array}$} & $5+2.5+1$ & 10 & 8 & 50 & Light green & $\begin{array}{l}\text { Nodular } \\
\text { compact }\end{array}$ \\
\hline & $5+1.5+2.5$ & 10 & 10 & 50 & $\begin{array}{c}\text { Whitish } \\
\text { green }\end{array}$ & $\begin{array}{l}\text { Smooth } \\
\text { compact }\end{array}$ \\
\hline & $5+2+3$ & 10 & 9 & 77 & $\begin{array}{c}\text { Light } \\
\text { brown }\end{array}$ & $\begin{array}{l}\text { Smooth } \\
\text { compact }\end{array}$ \\
\hline
\end{tabular}



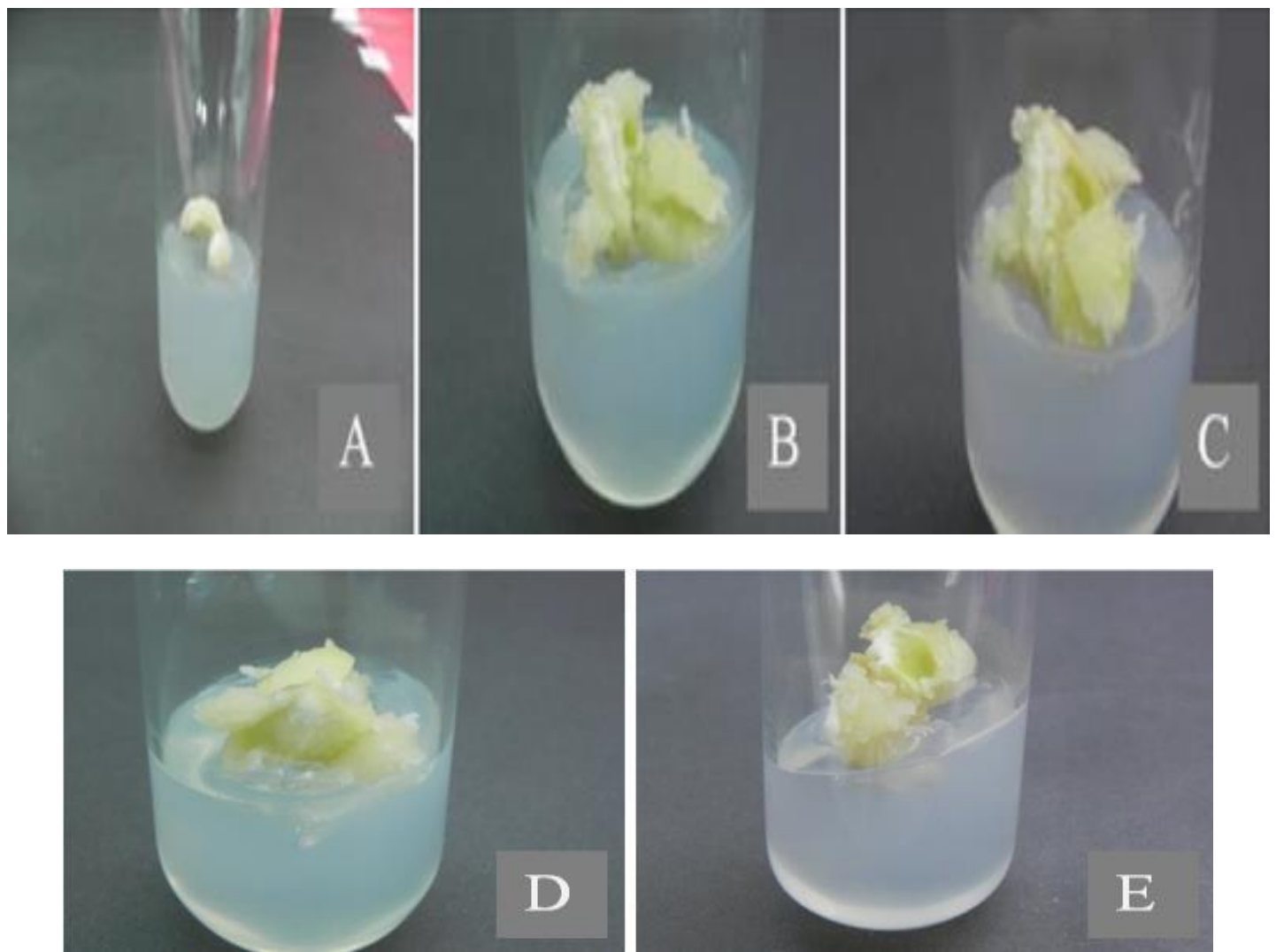

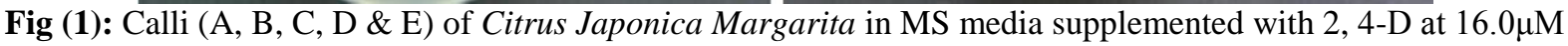

\section{Shoot proliferation from the callus of Orange}

For shoot regeneration green healthy calli obtained from previous steps of experiment were cut into small pieces and these pieces were cultured on MS medium supplemented with different concentration of BA and KIN alone and also their combination. After 35 day's shoot appears on some culture and extended shoot become visible after 40 days. Best shoot regeneration response $(80 \%)$ was observed on MS medium supplemented with BA $13.0 \mu \mathrm{M}$ (Fig. 2 \& 3) and (70\%) was observed on MS medium supplemented with BA $13.0 \mu \mathrm{M}$.

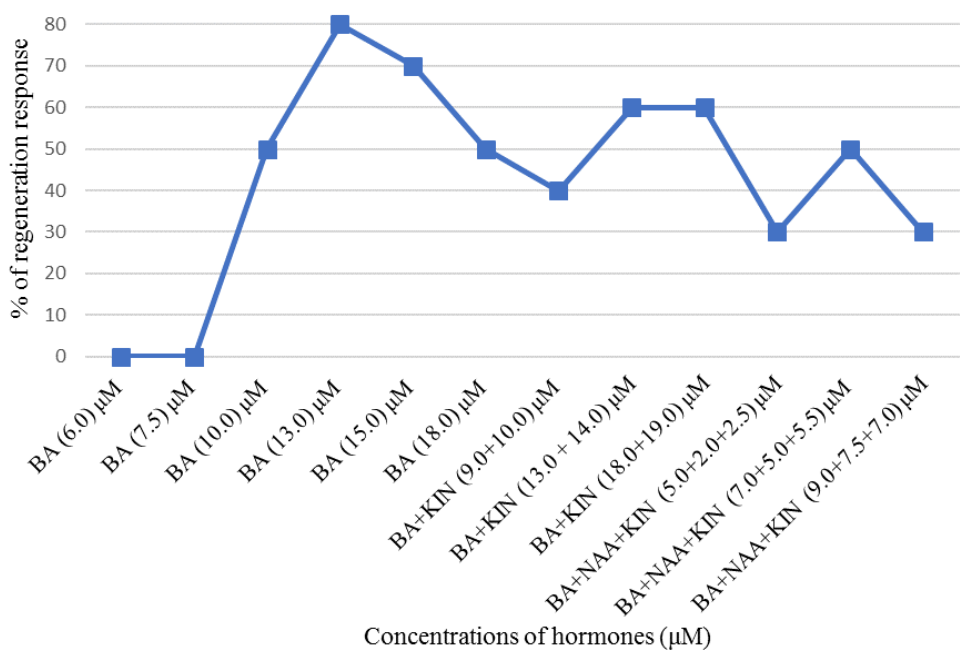

Fig (2): Effects of hormones on calli for shoot regeneration (KIN=Kinetin) 

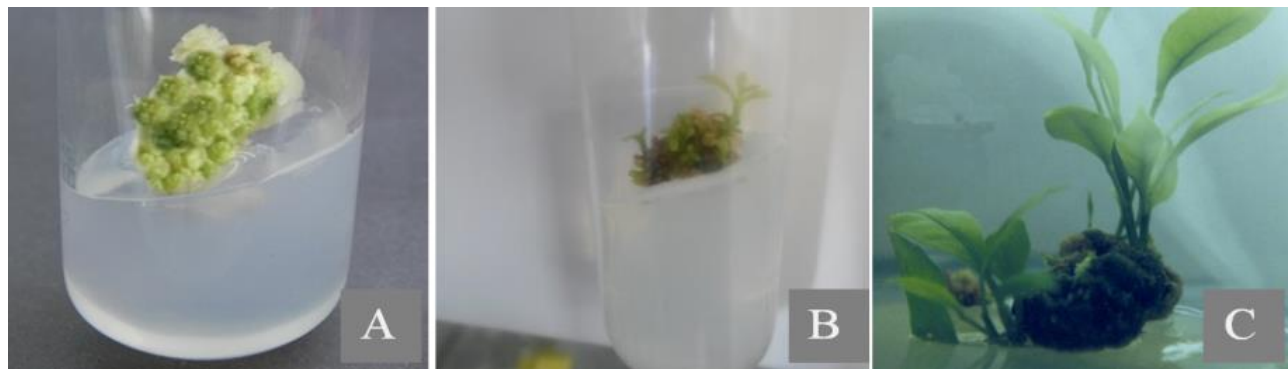

Fig. (3): Shoots regeneration of Citrus Japonica Margaritain MS media treated with BA at $13.0 \mu \mathrm{M}$. $\mathrm{A}=$ second week, $\mathrm{B}=$ third week, $\mathrm{C}=$ fifth week

\section{Root induction from the proliferated shoots of sweet orange}

For rooting development shoots cut off segments were cultured on rooting medium containing different concentrations of IBA, NAA and their combination. Roots appears within 21 days of inoculation. To become mature roots were needed 28 days. During acclimatization the actual no. of root and length of root were measured. Six different concentrations $(5.5,7,10,12,14,15 \mu \mathrm{M})$ of IBA and Two of NAA $(5,7.5)$ were added MS medium for root initiation. Combination of IBA with NAA were also used. $10 \mu \mathrm{M}$ IBA and $5 \mu \mathrm{M}$ of NAA shows $80 \%$ and $75 \%$ root regeneration respectively (fig. $4 \& 5$ ).

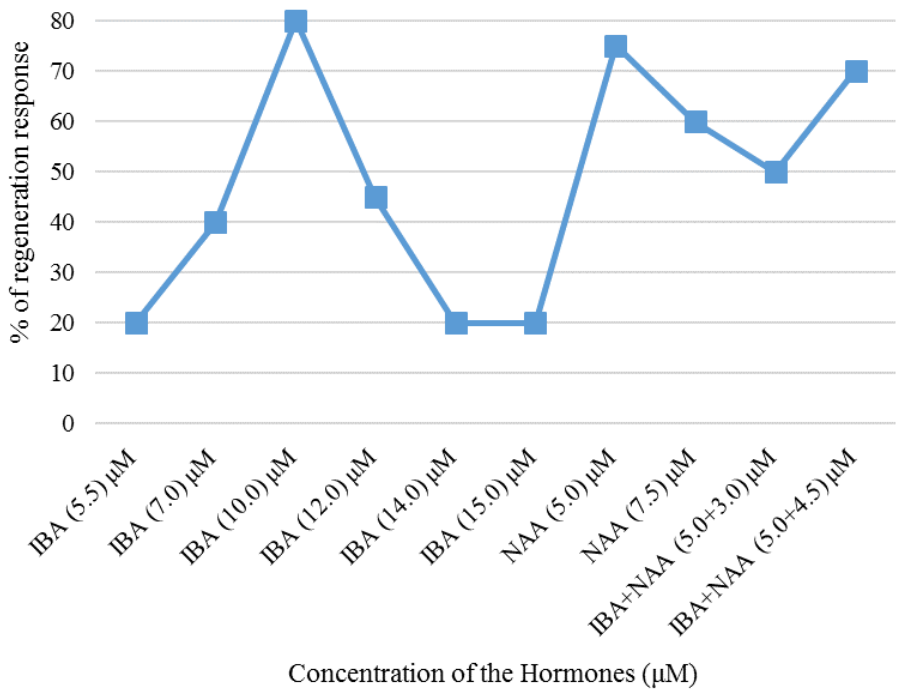

Fig. (4): Effects of IBA, NAA and their combination on rooting
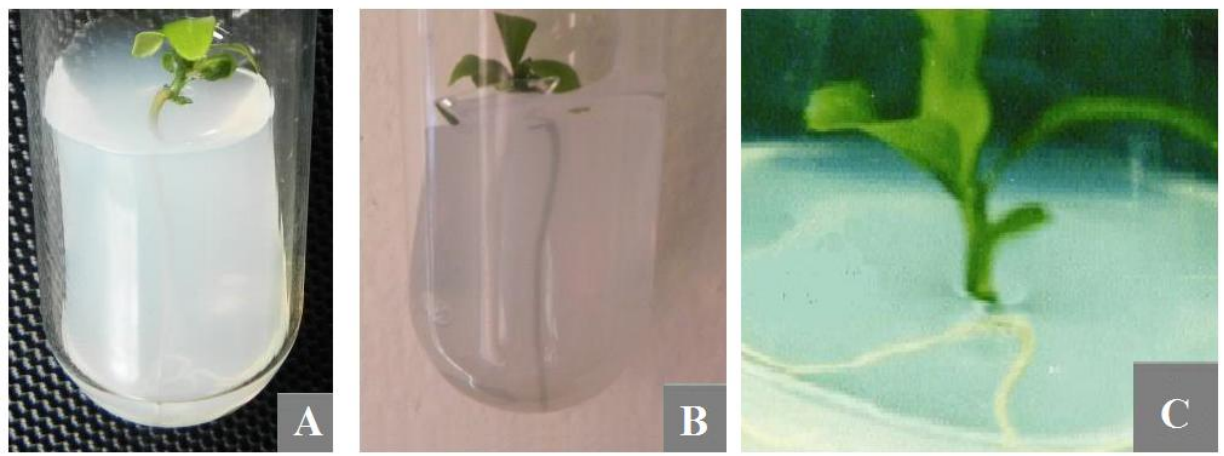

Fig. (5): In vitro rooting (A, B \& C) on MS $+10.0 \mu \mathrm{M}$ IBA

\section{Discussion}

The present study was designed to identify the ideal conditions for micropropagation of Citrus japonica because not much work has been done on the tissue culture and micropropagation ofthis plant. Citrus seeds have a very short life because they are injured by drying during storageand thus lose their viability. This is why freshly isolated seeds from orangewere used, these seed showed 75-80 germination capacity.The best callus induction response (88\%) of seed was observed on MS medium supplementedwith 2,4 - D $16 \mu \mathrm{M}$ followed by 
the MS medium supplemented with 2,4 D (5 $\mu \mathrm{M})$, BA $(2 \mu \mathrm{M})$ and NAA $(3 \mu \mathrm{M})$ is $77 \%$. Earlier also combination of BA and NAA have been shown tobe favorable for shoot regeneration from calli of different Citrus spp. (Chaturvedi and Mitra, 1974; Beloualy, 1991). Some studies have shown use of BA alone to be better treatment forshoot regeneration in different Citrus spp. (Raman et al., 1992; Costa et al., 2002). In this study50\% callus induction was found on $7 \mu \mathrm{M} \mathrm{BA}$ and it increases to $62 \%$ after increasing itsconcentration to $11 \mu \mathrm{M}$ BA. In this experiment, combination of BA with NAA was moreeffective as compared to the combination of BA and NAA with KIN. Gitaraniet al. (2003) andHaoaet al. (2004) got increased callus induction percentage with increasing levels of auxins,NAA and 2,4-D in the media. The present study is also in line with that also reported callusdevelopment in orange (Citrus japonica Margarita) on MS medium supplemented with $13 \mu \mathrm{M}$ 2,4D.Regeneration of different species of Citrus has been already investigated using MS mediumsupplemented with BA $3 \mathrm{mg} / \mathrm{l}$ or with BA $1 \mathrm{mg} / \mathrm{l}$ (Pena et al., 1995 and Dominguez et al.,2000). BA (1mg/l, 1.5mg/l) and KIN $(1 \mathrm{mg} / \mathrm{l}, 2 \mathrm{mg} / \mathrm{l})$ and BA in combination with $\mathrm{KIN}(2 \mathrm{mg} / \mathrm{l}+2 \mathrm{mg} / \mathrm{l}, 4 \mathrm{mg} / \mathrm{l}+3 \mathrm{mg} / \mathrm{l})$ were used successfully for shoot initiation. Maximum shootregeneration response $(80 \%)$ was observed on MS medium supplemented with BA 13 $\mu$ Mfollowed by $(70 \%)$ on half strength MS medium supplemented with BA $15 \mu \mathrm{M}$. There are somereports indicating KIN to be a better plant growth regulator treatment for shoot regeneration (Rahman et al., 1996). The lowest shoot regeneration response (30\%) was observed on MS medium supplemented with BA+NAA+KIN $(9+7.5+7) \mu \mathrm{M}$. Although the medium with $2 \mathrm{mg} / 1 \mathrm{KIN}$ resulted with low percentage of shoot proliferation but it gives highest number of shoots per explants around 16. Costa et al. (2002) reported shoot regeneration at BA from 0.5-4 mg/l for Citrus paradise (Macf.) epicotyl explants. Te-Chato and Nudoung, (1998) reported that BA $0.5 \mathrm{mg} / \mathrm{l}$ gave the best results (75\%) of shooting response in Citrus reticulata Blanco cv Shogun from different explants of in vitro raised seedlings. The present study showed better regeneration response than those cited in these reports. Inclusion of auxin in the medium has been found to be beneficial for shoot production in some cases (Chaturvedi and Mitra, 1974; Bhansali and Arya,1978). A medium containing $22 \mu \mathrm{M}$ BA with or without $5.4 \mu \mathrm{M}$ NAA was optimum for shoot initiation in all the three Citrus rootstocks (Moore, 1986). Micro shoots were shifted to rooting media containing different concentration of IBA, NAA alone and in combination. Maximum plantlets were obtained when IBA was combined with NAA. Maximum rooting was recorded when IBA is $10 \mu \mathrm{M}(80 \%)$ and NAA is $5 \mu \mathrm{M}(75 \%)$. In this study IBA was found to give better response as compared to NAA. On the contrary, NAA was found to give better response in Citrus acida(Chakravarty and Goswami, 1999). Other reports which showed NAA to be better rooting hormone for Citrus spp. included Pena et al., (1995); Chakravarty et al., (1999); Normahet al., (1997); Usman et al., (2005); Rani etal., (2004).

\section{References}

[1] V. Grinblat, Differentiation of citrus stem in vitro, Journal of the American Society for Horticultural, Science, 97, 1972, 599-603.

[2] H.C Chaturvedi, A.K Sharma, A shift in morphogenetic pattern in citrus callus tissue during prolonged culture, Indian Journal of Experimental Biology, 17, 1979, 153-157.

[3] H.C Chaturvedi, A.K. Sharma, In: Proc. Symp. Plant cell and Tissue Culture. Economically important plants, Hyderabad. India, 1987, pp 293-301.

[4] H.C Chaturvedi, G. Mitra G, Clonal propagation of Citrus from somatic callus cultures, Horticultural Science, 9, $1974,118-120$.

[5] H.C. Chaturvedi, S.K. Singh, A.K. Sharma, S. Agnihotri S, Citrus tissue culture employing vegetative explants, Indian Journal of Experimental. Biology, 39, 2001, 1080-1095.

[6] M. Barlass, K.G.M.Skene, In vitro plantlet formation from Citrus species and hybrids, Scientia Horticulturae, 17(4), 1982, 333341.

[7] M.H Edriss, D.W. Burger, In vitro propagation of troyercitrange from epicotyls segments, Scientia Horticulture, 23, $1984,159-162$.

[8] L. Pena, M. Cervera, J. Juarez, A. Navarro, J.A. Pina, N. Duran -Vila, L. Navarro, Agrobacterium-mediated transformation of sweet orange and regeneration of transgenic plants, Plant Cell Reports, 14, 1995a, 616-619.

[9] L. Pena, M. Cervera, J. Juarez, A. Navarro, J.A. Pina, N. Duran -Vila, L. Navarro, High efficiency Agrobacterium-mediated transformation and regeneration of Citrus, Plant Science, 104, 1995b, 183-191.

[10] Y.S. Parmessur, S. Alijanabi, S. Saumatally, A. Dookun-Samutually, Sugarcane yellow virus and sugarcane yellow phytoplasma: elimination by tissue culture, Plant Pathology, 51, 2002, 561-569.

[11] Z. Liao, M. Chen, F. Tan, X. Sun, K. Tang, Micropropagation of endangered Chinese Aloe, Plant Cell Tissue Organ Culture, 76, 2004, 83-86.

[12] J. Milkuk, Propagation of endangered plant species by tissue culture,ActaUniversitalisPalackianeaeOlomucensisFacultas Rerum NaruraliumBiologia, 37, 1999, 27-33.

[13] C. Chang, C. Chen, Y.Tsai, Y. Chang, A tissue culture protocol for a rare plant LiliumspeciosumVar. gloroiosoides Baker, Botanical Bulletin Academia Sinica, 41, 2000, 139-142.

[14] A. Jaime, T. Da Silva, Chrysanthemum: Advances in the tissue cultures, cryopreservation, post-harvest technology, genetics and transgenic biotechnology, Biotechnology Advances, 21, 2003, 715-766.

[15] J. Kochba, P. Spiegel-Roy, Embryogenesis in gamma-irradiated habituated ovularcallus of the 'Shamouti' orange as affected by auxin and by tissue age, Environmental and Experimental Botany, 17, 1977a ,151-159.

[16] S. Kobayashi, I. Ikeda, H. Uchimiya, Conditions for high frequency embryogenesis from orange (Citrus sinensisOsb.) protoplasts, Plant Cell Tissue Organ, Culture, 4, 1985, 249-259.

[17] E. Nicolosi, Z.N. Deng, A. Gentile, S. La Malfa, G. Continella, E. Tribulato,Citrus phylogeny and genetic origin of important species as investigated by molecular markers, Theoretical and Applied Genetics, 100 (8), 2000, 1155-1166.

[18] N. Beloualy, Plant regeneration from callus culture of three citrus rootstocks, Plant Cell Tissue and Organ Culture, 24, $1991,29-34$.

[19] H. Raman, S.S. Gosal, D.S. Brar, Plant regeneration from callus cultures of Citruslimonand C. jambhiri, Crop improvement, 19, 1992, 100-103. 
[20] M.G.C Costa, W.C. Otoni, G.A. Moor, An elevation of factors affecting the efficiency of Agrobacterium-mediated transformation of Citrus paradise (macf.) and production of transgenic plants containing carotenoid biosynthetic genes, Plant Cell Reproduction, $21,2002,365-373$

[21] G.S.V. Gitarani, N.A. Vinash, Callus induction and Plantlet regeneration in Sweet orange (C. sinensis L.) and Lime (C. aurantifolia). In vitro Cell, Development Biology, 39, 2003, 468-74.

[22] Y.J Haoa, X.P. Wen, X.X. Deng, Genetic and epigenetic evaluations of citrus calluses recovered from slow growth culture, Journal of Plant Physiology, 161, 2004, 479-484.

[23] Dominguez, J. Guerri, M. Cambra, L. Navarro, P. Moreno, L. Pena, Efficient production of transgenic citrus plants expressing the coat protein gene of citrus tristeza virus, Plant Cell Reports, 19, 2000, 427-433.

[24] A.A.S. Rahaman, V. Nagaraju, V.S Parthasarthy, Response of embryoids of certain Citrus species to two cytokinins, Annual Review of Plant Physiology 10, 1996, 45-49.

[25] S. Te-Chato, S. Nudoung, Tissue culture of Citrus reticulataBlanco CV. Shogun and gene transformation by Agrobacteria, Proc. Abstracts IMT-GT UNITE Conf, Songkxhla, 1998.

[26] R.R. Bhansali, H.C. Arya, Tissue culture propagation of citrus trees, International Society of Citriculture, 1, 1978, 135-140.

[27] B. Chakravarty, B.C. Goswami, Plantlet regeneration from long term callus cultures of Citrus acidaRoxb. and the uniformity of regenerated plants, Scientia Horticulturae 82, 1999, 159-169.

[28] M.N. Normah, S. Hamidoh, F.D. Ghani, Micropropagation of Citrus halimiian endangered species of South-east Asia, Plant Cell, Tissue and Organ Culture, 50, 1997, 225- 227.

[29] M. Usman, S. Muhammad, B. Fatima, In vitro multiple shoot induction from nodal explants of Citrus cultivars, Journal of Central European Agriculture 6, 2005, 435-442.

[30] G. Rani, B. Singh, S. Sharma, L. Rehan, A.A. Zaidi, A. Nagpal, G.S. Virk, Micropropagation of Kinnow (Citrus nobilis x Citrus deliciosa) through nodal segments, Journal of Indian Botanical Society 83, 2004, 26-29. 